\title{
Specificities and Limits of Taiwanese Nationalism
}

\author{
Jean-Pierre Cabestan
}

\section{OpenEdition}

Journals

Édition électronique

URL : http://journals.openedition.org/chinaperspectives/2863

DOI : 10.4000/chinaperspectives.2863

ISSN : 1996-4617

\section{Éditeur}

Centre d'étude français sur la Chine contemporaine

\section{Édition imprimée}

Date de publication : 1 décembre 2005

ISSN : 2070-3449

\section{Référence électronique}

Jean-Pierre Cabestan, "Specificities and Limits of Taiwanese Nationalism », China Perspectives [En ligne], 62 I november - december 2005, mis en ligne le 01 décembre 2008, consulté le 28 octobre 2019. URL : http://journals.openedition.org/chinaperspectives/2863; DOI : 10.4000/ chinaperspectives.2863

Ce document a été généré automatiquement le 28 octobre 2019

(c) All rights reserved 


\title{
Specificities and Limits of Taiwanese Nationalism
}

\author{
Jean-Pierre Cabestan
}

1 Taiwanese nationalism is, in many ways, specific. On the one hand it is a recognised phenomenon. On the other, as the product of a young state, the Republic of China in Taiwan, which is threatened by the People's Republic of China, and isolated on the diplomatic level, this nationalism is controversial. It is sufficiently powerful to be perceived as an important factor in the evolution of Formosa and of its relations with the Chinese mainland, but not enough to avoid being the object of deliberate promotion by some of the island's political players, particularly the government of Chen Shui-bian. Complex, plural and essentially Han, Taiwanese society remains divided about its future, particularly when faced with the prospect of the island's independence, which is to say of a definitive break with China. The opposition of the People's Republic and of a large part of the international community to independence accentuates these divisions. Moreover, since 1987, Taiwan has established ever closer economic and human ties with precisely the country which denies it any sovereignty. The nationalism forged by the Taiwanese state cannot ignore these external constraints. While the verbal and military threats from Peking have contributed to reinforcing this nationalism, its nature, its limitations and its future are open to question ${ }^{1}$.

2 Taiwanese nationalism today constitutes an unavoidable reality. At the same time, it is in many ways specific. Built on a state-the Republic of China (ROC), a regime founded by Sun Yat-sen in Nanking in 1927, and which took refuge in Taiwan in 1949-stemming directly from the chinese nation, this nationalism is still founded on an "imagined community" which is relatively recent (fewer than sixty years have gone by, and fewer than twenty since the beginning of the democratisation of the island), and which is contested and claimed by the People's Republic of China (PRC), and therefore isolated on the diplomatic level.

3 A nationalist current has long existed in Taiwan that one could call fundamentalist, which favours pure and simple independence and is convinced that Taiwanese culture 
does not belong to Chinese culture. However, for reasons which are both internal and international, it has little hope of winning the support of a majority of Taiwanese. On the other hand, the identification, beginning in 1949, of the Republic of China with Taiwan has favoured the emergence of a Taiwanese national consciousness that the democratisation of the island, beginning in 1986, has consolidated. In other words, and in confirmation of the thesis of Gellner or of Hobsbawm ${ }^{3}$, the state of the Republic of China, by default Taiwan after 1949 , is the main ferment of Taiwanese nationalism. To such an extent that, steeped as it still is in Chinese culture, the island's society has built a Taiwanese cultural identity and political identity that Peking's intransigence on the question of Chinese sovereignty has contributed to reinforcing. Thus the majority of Taiwanese are now "sovereignists" in the sense that after fifty years of nation-building -initially imposed and then desired-they feel that only the Republic of China in Taiwan-and not the People's Republic-can represent them both internally and on the international scene. Taiwanese nationalism centres-and has thus built and rebuilt itself-on this complex reality which makes it more particular, moderate and plural than ambiguous-is any nationalism devoid of ambiguity and contradictions?-, but allows it to remain open to a compromise with Chinese nationalism, if the latter manages to take its existence into account, and to make a place for it within the Chinese nation ${ }^{4}$. If the opposite proved to be the case, Taiwanese nationalism could to a certain extent become more radical and become a further obstacle to building peace in the Strait of Formosa.

Taiwanese nationalism: roots that were geographical before becoming historical

4 The roots of Taiwanese nationalism were geographical before becoming historical. Taiwan's insularity explains a number of historical developments that have taken place since this land, which lies 150 kilometres off the coast of Fujian, and was mainly peopled by Austronesians (in 1600 they numbered fifty thousand on the plains and probably another fifty thousand in the mountains, as against about twenty-five thousand Chinese) was colonised, first by the Dutch (1624-1661) and the Spanish (1626-1642), and then by the Chinese. It was in fact Taiwan's insularity which allowed General Koxinga (Zhen Chenggong), who was loyal to the Ming dynasty, to establish and maintain there, for over twenty years, a Chinese regime opposed to the Manchus $(1661-1683)^{5}$. It was also its insularity which contributed to the transformation of Taiwan, after being conquered and annexed by the Manchu Empire in 1683, into a "frontier region". In fact, Peking administered only the western plains-leaving the aborigines in the mountains in de facto independence-and closely supervised the increase in the Han population (which from 130,000 in 1684 had risen to 2.5 million by 1893), in order to limit conflict with the Austronesian peoples. Also, lying at the intersection of international sea trade routes, Taiwan, by the mid-nineteenth century, aroused the covetousness of the Great Powers of the time, in particular of Great Britain, of France (whose Courbet expedition failed in 1884-1885) and of Japan, which saw Taiwan as the "natural" extension of the Ryukyu Archipelago. It was also these designs which incited the Manchu court (including Li Hongzhang) to modernise the island, to reinforce its security, and to raise it to the rank of a province in 1885 , before having to cede it to the Japanese Empire ten years later. Finally, in 1949, having for a while considered taking refuge on the island of Hainan, Chiang decided to transfer his regime provisionally to Taiwan because its insularity, its distance from the mainland, and the military defences built by the Japanese protected him much better than any other geographical or military frontier from Mao's essentially land-based forces. In other 
words, Taiwan's insularity is the direct cause of the co-existence for over half a century of two rival Chinese political regimes.

But insularity has also favoured in Taiwan, even when it was under the power of the Chinese mainland (before 1895 and between 1945 and 1949), the formation of a sociocultural sense of identity, which, despite the demographic hegemony of the Han, has always been deeper than in the country's other Han provinces. This sense of identity was fed by Chinese immigration, mainly from Fujian, a landlocked province which has always tended to turn away from the imperial capital ${ }^{6}$.

6 The second characteristic of Taiwanese nationalism is that it has been much more fed by the opposition between the mainlanders who arrived with Chiang in 1945-1949 (waishengren, about $13 \%$ of the population today) and native Taiwanese (benshengren, $87 \%$ ), than by the desire to separate from the Chinese nation. When, under the terms of the treaty of Shimonoseki, Taiwan came under Japanese domination in 1895, the island's population tried to resist this occupation. For example, a number of Manchu mandarins and local notables decided then to found a Republic of Taiwan (Taiwan minzhuguo). However, despite what certain Taiwanese nationalists assert today, the aim of this initiative was not to establish some sort of independence for the island. It was part of a project to return Taiwan to the Chinese Empire, which was invited to maintain its suzerainty and its protection of the territory, which had been momentarily lost $^{7}$. A sizeable portion of the Taiwanese opposition to Japanese colonisation continued to pursue this objective, while another more realistic and more influential group (represented in particular by Li Hsien-tang) concentrated its demands on the establishment of political autonomy within the Japanese empire. But the policy of forcible assimilation adopted by Tokyo in 1936, shortly before the outbreak of the SinoJapanese war, destroyed these hopes, and developed in Taiwan a resentment against a particularly repressive occupier, which goes much deeper than Taiwanese nationalists will admit today ${ }^{8}$. This was the reason why, in 1945, Chiang Kai-shek's troups were welcomed as liberators by the Taiwanese.

7 It is true that this perception did not last long. The incompetence and corruption of the new administrators, their distrust of a population whose degree of "nipponisation" they overestimated", and then the repression which followed the local revolt on February 28th 1947 permanently destroyed the Taiwanese dream of a harmonious return to the Chinese nation. February 28th also produced a two-fold phenomenon which was to prove lasting: on the one hand, a feeling of nostalgia for the Japanese period, whose colonisation, uncompromising though it was, is nowadays described by Taiwanese nationalists, if not as a golden age, at least as an era of economic and institutional modernisation, and even of emerging local democracy (between 1919 and 1936); and on the other hand, the affirmation of a Taiwanese consciousness (Taiwan yishi) and a Taiwanese identity (Taiwan rentong) based on a specific historical path, as well as a demand for autonomy and democracy on the part of the Taiwanese elites which has gradually given birth to a genuine independence movement ${ }^{10}$.

8 For, in 1945 or 1947, continuing a demand which had been put forward during the Japanese occupation, the great majority of these elites were not calling for independence but a certain form of autonomy ${ }^{11}$. It is true that after February 28th, a few activists, such as Liao Bun-gei (or Thomas Liao Wen-yi), called on the United Nations to establish a Mandate or Trusteeship in Taiwan, in order to allow the population to decide by referendum what the final status of the island would be 
(independence or belonging to the PRC). This trend was very much in a minority, and soon went into exile in Japan ${ }^{12}$. In the repressive context after February 28th, which was also marked by the civil war on the mainland and the preparations for the transfer of the nationalist government to Taiwan, the majority of the elites could not really conceive of any demands for independence.

In other words, much more than Japanese colonisation, it was the lasting separation of China into two distinct states which formed the basis for the Taiwanese independence movement and made it possible for Taiwanese consciousness and identity to change into nationalism. Consequently, the geographical and historic specificities of Taiwanese nationalism have not in any way weakened what is now the classic thesis of Gellner or Hobsbawm, according to which the state precedes the nation: Taiwan constitutes a perfect, though obviously specific, illustration of this thesis ${ }^{13}$.

In 1950, the conversion of the United States to a One-China policy slowed the growth of this movement. The hesitation of President Truman, who was tempted, after the outbreak of the Korean War (in June 1950), to reactivate the idea which had been put aside since the Cairo Conference of making Taiwan a United Nations trusteeship, probably kept alive for a while the hopes of the small independence movement which, as we have seen, was already in exile in Japan. This American position was, however, dictated more by the strategy of containment of communism in Asia than by any desire to call into question past commitments ${ }^{14}$. From 1953, Eisenhower gave unqualified support to Chiang and his ROC in exile, contributing to the maintenance of an international standing which was out of proportion to its real power (including a permanent seat on the UN Security Council). The Two Chinas policy that Washington sought to formalise during the 1960s, in particular after the recognition of the Peking government by Paris in 1964, was merely a short-lived episode, even though it found a favourable echo in the ranks of the Taiwanese opposition, known as dangwai (nonParty).

Moreover it was in 1964 that the Director of the Political Science Department of the National University of Taiwan, Peng Min-min, was arrested for having criticised Chiang's plans to reconquer the mainland, called for the democratisation of Taiwan and denied that the island was part of China, proposing the peaceful co-existence of two states on the world stage and within the United Nations ${ }^{15}$. In thrall to the old ROC, and believing, wrongly, that the Peking regime was on the brink of collapse, Chiang remained opposed to any "Two Chinas" policy. This obstinacy led to a faster adjustment of American policy. From 1971, obsessed by the Soviet threat, the United States, on Kissinger and Nixon's initiative, definitively abandoned any vague desire to have the existence of two Chinese states officially ratified by the international community, formally maintaining a single China policy which went against Chiang (the replacement of the "Chiang Kai-shek clique" by the regime in Peking at the UN in 1971, the joint Chinese-American Declaration of Shanghai in 1972). Apparently satisfying both Mao and Chiang, this change prefigured the normalisation of Chinese-American relations in 1979, and set out the foundations of a China policy from which the United States has not deviated since.

These events had two main consequences: on the one hand, they increased opposition pressure for the democratisation of the Taiwanese regime; on the other they strengthened Taiwanese nationalism and in particular its independence movement. The expulsion of the ROC from the UN followed by "de-recognition" by the United 
States discredited the KMT's single-China policy. Reduced to the rank of a "non-state" ${ }^{16}$, how could the ROC continue to claim that it represented the Chinese nation? And, conversely, how could the PRC claim to represent Taiwan on the international scene?

Democratisation, diplomatic isolation and Taiwanese nationalism

By 1972, a process of Taiwanisation of the administration and of cautious political liberalisation was begun by Chiang Ching-kuo, son of Chiang Kai-shek (deceased in 1975), who had become Prime Minister. But this evolution quickly favoured the growing strength of a Taiwanese identity movement which was both cultural (particularly literary) and political, and whose best-known vector was the magazine Meilidao (Formosa) ${ }^{17}$. Using as its title the Western or "pre-Chinese" name for the island, this publication symbolised the merging of demands for democracy and demands for self-determination. The banning of Meilidao and the arrest of its prime movers in December 1979, in the context of the increasing diplomatic isolation of the ROC, helped to reinforce this merger, whose political manifestation was the creation in 1986 of the Democratic Progressive Party (DPP) the main opposition party to the KMT ${ }^{18}$.

The year 1986 is thus a turning point in the political history of Taiwan and of Taiwanese nationalism. For the first time, Chiang Ching-kuo decided to tolerate the establishment of a party led by native Taiwanese and which promoted Taiwanese consciousness and identity, if not overtly the independence of Taiwan. This decision was part of a strategic change of direction in the KMT, the two main pillars of which were closely connected: on the one hand the suspension of martial law (in July 1987) and the gradual democratisation of institutions (beginning in 1991); on the other, the opening of indirect trade and human links (via Hong Kong) with the PRC (autumn 1987). Without recognising the Peking regime, Chiang took account of a reality which led ipso facto to an assumed political identification (without however being legal) between the ROC and Taiwan, or more precisely the territories placed under the jurisdiction (WW guanxia) of Taipei: Taiwan, the Pescadores, Kinmen and Matsu' ${ }^{19}$. Completed by Lee Teng-hui, a native Taiwanese, after the death of Chiang Ching-kuo in January 1988, this fundamental change unleashed Taiwanese nationalism and desire for independence, but also channelled it through the democratic contest, which highlighted its ambiguities and limitations.

Since its foundation the DPP has been divided by divergent trends and the independence faction, which is to say those whose priority was a clear and definitive break between the Chinese nation and the Taiwanese nation, were in a minority. The main stake at the time was the democratisation and therefore the Taiwanisation of the political system. It is true that the events of Tiananmen on the mainland, the political reforms introduced by Lee Teng-hui beginning in 1991, the establishment of an unofficial channel of communication between Taipei and Peking and the adoption by the KMT government of a long-term programme for the reunification of China, were all factors which contributed to strengthening the cause of independence. Thus in 1991, in response to requests from Chen Shui-bian and others, the DPP added to its statutes the famous clause in favour of the self-determination of Taiwan, which proposed to make it obligatory for the island's leaders to submit any decision concerning the definitive status of the island to the approval of the population ${ }^{20}$. However, the more clearly independence-minded line adopted by the DPP at the time cost it votes, which prompted it to quickly moderate its discourse. Thus by 1995 , the DPP, which was then presided by Shih Ming-teh, decided to settle for the status quo, and, like the KMT 
(including the New Party, a dissident formation of the KMT), based its international campaign on the improvement of Taiwan's diplomatic status and particularly its return to the UN.

In other words, the democratisation of Taiwan created a new consensus, which one might call "sovereignist", between the Taiwanised KMT and the DPP: the "ROC in Taiwan" is a sovereign state whose future can only be determined by the Taiwanese themselves. While it does not rule out a priori any future unification with a democratic China, this new consensus gives priority to the development, security and survival of the island as a Nation state that is already independent, and to the consolidation of its democracy. From now on, despite the rivalries which divide them, all the Taiwanese political parties have to take into account and integrate this new consensus along with the "civic" nationalism it has produced"

The consolidation of Taiwanese nationalism since the 1990s

Since the 1990s, Taiwanese nationalism has affirmed itself clearly. This increased power is the result not only of democratisation but of a dialectic process where the local political forces which promote it have been reinforced by the PRC's hostility towards it. The result has been a certain radicalisation, of a nativist - which is to say seeking to favour the promotion of native Taiwanese at the expense of their fellow countrymen of mainland origin - not to say fundamentalist nature.

The increasing power of Taiwanese political and cultural identity

The affirmation of Taiwanese identity is a recognised phenomenon. While the opinion polls can give varying results, they all highlight the same trend: the majority of citizens in the ROC today consider themselves to be Taiwanese (between $45 \%$ and $50 \%$ depending on the source, as against $14 \%$ in 1992), or at least Taiwanese and Chinese (between $39 \%$ and $41 \%$ as against $33 \%$ ), but only rarely Chinese (between $8 \%$ and $11 \%$ as against $49 \%{ }^{22}$. According to some sources close to the DPP, at the end of 2004, close to two-thirds of Taiwanese (61\%) favoured the first choice, only $16 \%$ the second and $14 \%$ the third ${ }^{23}$.

19 This undeniable change covers a gradual metamorphosis in the political, and also to some extent the cultural identity of the Taiwanese. Favoured by the rehabilitation of Taiwanese culture which had long been repressed by the minority from the mainland which dominated the island between 1949 and 1987, this transformation has mainly made possible an increase in the power of the minnan community (also called Hoklo, $70 \%$ of the population) and of its dialect, which by the end of the 1990s was promoted to the rank of second official language of the island. It has also given rise to a greater taking into account of the diversity of human groups in Taiwan and of the languages they speak, in particular Hakka spoken by $15 \%$ of the population) and the main Austronesian dialects (atayal, tsou, ami, paiwanic, etc.). Thus has been constituted a discourse that is both universalist (democracy and economic globalisation) and nativist (Taiwanese),and which has gradually become the dominant discourse of the political class (including Lee Teng-hui's Taiwanised KMT), calling for recognition both of Taiwan's status as a state under international law and of a historical and cultural specificity which differentiates it from the PRC ${ }^{24}$. In 1997, the revision of school books and the introduction of the teaching of Taiwanese history, conceived separately from the study of Chinese history, was one of the outcomes of this change ${ }^{25}$. A year later, in the autumn of 1998, seeking to bring together the various communities on the island, and in particular to favour the election of the KMT candidate of mainland origin Ma 
Ying-jeou to the mayoralty of Taipei, against the incumbent mayor Chen Shui-bian, Lee Teng-hui launched the concept of the "New Taiwanese" (xin Taiwanren/sin Taiwanlang). Through this unifying slogan, Lee also sought to consolidate the sovereignist consensus referred to above.

Nonetheless, this discourse shows the extent to which Taiwanese identity has been constructed not by itself, in a somehow essentialist manner, but in reaction to the traditional approach to Chinese culture and history developed by the KMT (up to the 1990s) and by the Communist Party, as well as to Chinese nationalism and thus to the irredentist claims of Peking. Aimed at countering the rise of Taiwanese nationalism, the intensification of the psychological and military pressure from the People's Republicparticularly during the missile crisis of 1995-1996 and the mini-crisis of 1999 provoked by Peking with the aim of stigmatising Lee Teng-hui's "two nations theory", as well as the threatening official report in February 2000-has on the contrary stirred it up.

Prior to 1995, the KMT government still sought to reconcile the principle, admittedly revised, of a single China with the rise of Taiwanese identity. For example, the "Official report on the relations between the two shores of the Strait" in 1994 declared that Taiwan henceforth constituted not a country but a political entity (zhengzhi shiti), a "community of life" (shenghuo gongtongti), a Gemeinschaft, whose future-unification with China or definitive separation-depended mainly on the attitude of Peking. But in July 1999, China's economic and political emergence and its determination to win over the United States to its cause, prompted Lee Teng-hui to take a further and probably decisive step. As he saw it Taiwan (ROC) constituted a separate country from (the People's Republic of) China and their relations could only be "particular relations between one State and another" (tesu de guo yu guo de guanxi). This new description shocked Peking and prompted it in February 2000 to raise any procrastination sine die by Taiwan of the negotiations on reunification into a casus belli. Washington judged Lee to be responsible for this new crisis. Nonetheless, over $70 \%$ of Taiwanese gave their president approval, thus confirming and consolidating the new consensus that had appeared in Taiwan during the 1990s. Moreover, this progression of Taiwanese identity affected all the island's communities, including the mainlanders, in particular those of the second or third generation, all of whom were born on the island and speak or understand the Hoklo dialect. Already in 1997, $42.9 \%$ of the descendants of mainlanders born between 1968 and 1981 declared themselves to be Taiwanese, as against only $27.6 \%$ of those born before $1968^{26}$. Finally, Taiwanese identity was increasingly instrumentalised by the Taipei government in order to try to bring the country out of its diplomatic isolation, both by looking for new diplomatic allies, particularly in Africa and in the South Pacific, and by developing a pragmatic diplomacy-towards Asian countries which had official relations with Peking-which has almost constantly enjoyed public support ${ }^{27}$.

In such circumstances, it is hardly surprising that, conversely, $75 \%$ of Taiwanese are opposed, not only to the formula favoured by Deng Xiaoping "one country, two systems", but to any reunification ${ }^{28}$. While, because of the military threat of the People's Liberation Army (PLA), they are more favourable to the maintenance of the status quo (around 60\%) than to formal independence for the island (around 20\%, including 5 to $7 \%$ without delay), they identify with a country which, for historical reasons and for a growing number of them by default, is called Republic of China but which is in reality Taiwan ${ }^{29}$. Moreover, each time tensions in the Strait rise, supporters 
of the status quo increase while supporters of any reunification, even in the long term, decrease. This is why, although the propaganda from Peking now seeks to "win the hearts of the Taiwanese", it has so far managed only to sharpen their political identity and their nationalism.

In fact, the increase in economic and human ties between the two shores of the Strait has not up to now succeeded in bringing the Chinese and Taiwanese identities closer together. Of course, favoured by the economic opening up and the very relative political liberalisation of the Peking regime, these relations have made possible better mutual knowledge and, by forging ever closer interdependent links, have contributed to increasing the cost of any military conflict, first for Taiwan but also for the People's Republic of China. Moreover, sensitive to the political environment in which they operate, about two-thirds of the Taiwanese businessmen (or Taishang) resident on the mainland (who number over a million today) feel closer to the Blue Camp (the KMT and the People First Party (PFP) or Quinmindang) than to the Green Camp (the DPP and the Taiwan Solidarity Union (TSU) or Taiwan tuanjie lianmeng) ${ }^{30}$. Nonetheless, as mostly native Taiwanese, who speak the Hokkien dialect among themselves, the Taishang as a whole continue to identify with Taiwan, forming a community on the mainland which shares most of the characteristics of other "expatriate" communities ${ }^{31}$. In the search for their roots, the Taiwanese of mainland origin are more likely to try to reintegrate with mainland society. However, this desire is often frustrating and rarely complete, so Taiwanised is this community today, and thus incited-by both their compatriots and the Chinese authorities-to remain united with the other Taishang. Moreover, the many Taiwanese tourists who visit China today generally come back with a clearer sense of their own "Taiwanicity", which is to say of their identification with the Nationstate to which they belong.

24 Finally, while over three million visits by Taiwanese are counted every year in the People's Republic, about two-thirds of the island's inhabitants have never been there. It is often the same Taishang (or the same tourists from the island) who make the return journey several times a year. But probably because of this growing economic and human integration with the mainland, since the election of Chen Shui-bian in 2000, Taiwanese nationalism has taken on a more nativist form, which one might call fundamentalist, and which paradoxically has highlighted the ambiguities and limitations of this phenomenon.

Taiwanese nationalism's fundamentalist temptation: the "de-sinisation" of the island

As we have seen, there has existed in Taiwan since 1945 an independence movement which bases its demands on an identity which is not only political but also cultural and ethnic and completely different from the Chinese identity; this is what I call the fundamentalist trend. Formerly represented by Shih Min who believed that the 400 years of Taiwanese history were those of a people who, by crossing the strait, had sought to free themselves from the Chinese yoke $^{32}$, this movement seeks to demonstrate that Taiwanese cultural habits are not part of the Chinese (or Han) cultural sphere, and believes that because of the widespread interbreeding between Austronesians and Chinese immigrants, the Taiwanese ethnic group (Taiwan minzu) is racially different from the Han. While it is very much in a minority within the DPP, it is much more influential within Lee Teng-hui's TSU, which spreads its ideas. These are also fairly widespread in pro-Taiwan organisations in the United States and in Japan ${ }^{33}$. 
26 Nonetheless, in order to win the support of the independence movement, to politically isolate an opposition which was tempted, after its historic defeat in March 2000, by the "resinisation" of its discourse, and in order to affirm Taiwan's specificity abroad, Chen Shui-bian has sought to instrumentalise the pressure from this movement. It is thus that his government implemented a cultural and educational "de-sinisation" policy of a much more systematic nature than that of his predecessor, substituting a highly voluntarist "Taiwano-centric" policy ${ }^{34}$. Any cultural event deemed to be typically Taiwanese is now encouraged (including financially) and presented as such, at the risk of giving too much importance to the Austronesian cultures, while everything which could on the contrary maintain a connection with China is relegated to the background. Taiwan's unofficial embassies abroad have been put in charge of spreading this new tropism ${ }^{35}$. Similarly, the authorities in Taipei have pursued their revision of school curricula, introducing in 2001 in high schools a very controversial teaching of history which gives greater importance to the study of Taiwan after 1500 (aimed at foregrounding its Austronesian identity and the Dutch colonisation), and then announcing in 2004 the establishment of three new pillars for the spreading of this discipline: Taiwan, Asia (including China), and the rest of the world.

Moreover Chen Shui-bian's government has attempted-so far unsuccessfully-to rewrite the content of this teaching. However in 2004 he asked state-financed organisations (such as the Foundation for Taiwanese Democracy whose director is the deputy Minister for Foreign Affairs, Michael Kao Ying-mao) to propagate the idea that the return of Taiwan to China in 1945 was a decision taken by the United States, and imposed on the islanders by General Mac Arthur without their being consulted ${ }^{36}$. Also in June 2005, he introduced on the Government Information website a history of Taiwan written by Huang Fu-san which elaborates an independence interpretation of the island's Chinese past. Thus, Koxinga is presented as one of the distant fathers of the Taiwanese quest for independence ${ }^{37}$. On the linguistic level, Chen Shui-bian's government has raised Hokkien or Minnan) to the status of a quasi-official language and favoured the distribution of books in this vernacular dialect, although it is far from possible to transcribe it completely in Chinese characters (not to mention the endless debates on its range of romanisations $)^{38}$.

28 Lastly, he has decided to promote a post-modern multiculturalism, no doubt imported from California, with the avowed aim of diluting the chinese cultural legacy into a melting-pot where Japanese, American and European contributions are given an importance equal to the Chinese inheritance. After testing by Taiwan zhiku (Taiwan Think Tank $)^{39}$, a group close to the DPP, this multiculturalism was officially adopted by the party in September 2004. It approved a "resolution on (sub)ethnic diversity and national unity" which, while rejecting on principle the exclusion of any group, considers the mainlanders, the Hoklo and the Hakka, despite their being all Han, as distinct "ethnic subgroups" (zuqun), in the same way as the Austronesians, the better to bring them together within a "de-sinised" Taiwanese national identification and to transform Taiwan into a "paradigm of multiculturalism"

29 More generally, however, Chen Shui-bian and the DPP have made this nativist nationalism the main theme of their politics, ostracising, in order to marginalise them, those mainlanders who, although they are Taiwanised, have remained influential within the army, academia and the opposition parties ${ }^{41}$. The foregrounding of the Austronesian roots of the native Taiwanese has moreover given birth to a new form of 
snobbery, with politicians and island personalities claiming an aboriginal ancestor who once would have been shamefully concealed. The Prime Minister Hsieh Chang-ting went so far as to reveal to the public this new "good Taiwanese nationalist's certificate" ${ }^{42}$. One can see here the dangerous distortions of a conception of the Taiwanese nation which is moving further and further away from the inclusive notion of a "community of destiny", in order to substitute an exclusive definition of a nation based on a particular racial blend.

However, having shown its effectiveness during the presidential election in March $2004^{43}$, this nationalist policy reached its own limits in the subsequent general election in December 2004. The new Parliament remained virtually identical to its predecessor, giving once again the majority of the 225 seats to the Blue coalition (KMT: 79 seats, PFP: 34 seats) and keeping the Green camp in its previous position (DPP: 89 seats; TSU: 12 seats $)^{44}$.

31 While there are many reasons for this result, one can consider that Chen also paid the price in December 2004 of an excessively univocal and extreme promotion of Taiwanese nationalism, shattering the consensus which had been forged during the 1990s around, on the one hand the identification of the Republic of China with Taiwan, and on the other, the maintenance of the status quo in the Strait ${ }^{45}$.

The limits and the plural character of Taiwanese nationalism

In fact, the propagation of nationalism and especially of Taiwanese nativism by the DPP in government has contributed to intensifying the polarisation of island society. It has also provoked an increase in pressure from China and in American anxiety. In the context of globalisation and of the economic integration between the two shores of the Strait of Formosa, it especially highlighted the schizophrenic character of Chen's policy, and hence the limits and plural character of Taiwanese nationalism.

It is clear that Taiwanese nationalism today constitutes an essential common value of the political class as a whole: the need felt by the opposition candidates, the extremely wealthy Lien Chan (KMT) and the mainlander James Soong Chu-yu (PFP) to kiss the soil of Taiwan during the 2004 presidential campaign confirmed the unavoidable character of the identity discourse summed up by the slogan "Love Taiwan". However, the new government's discourse revealed itself as much more exclusive than inclusive. First of all it accentuated a feeling of crisis within the mainlander community who, although Taiwanised, have trouble accepting the new cultural tropism of the Green Camp. Also, this discourse contributed to the reawakening of a "provincial origins complex" (shengji qingjie) which had gradually faded away after the process of democratisation and maturing of the DPP, a party which had been too often tempted to exclude the mainlanders. While the cultural activism aimed at the Hakka community was well received (and turned out to be very productive in electoral terms), it speeded up the alienation not only of the mainlanders, whose allegiance to Taiwan has often, and generally unjustly, been called into question, but of the many Taishang who, established in the People's Republic, are increasingly worried by their government's identitarian and "localist" isolation. The nativism of the island's present government has led them to eclipse both the permanent hybridity of Taiwanese identity ${ }^{46}$ and the process of economic and human integration with the mainland, despite having recognised its reality in 2001.

Indeed, since 1999 a virtually constant number of people polled consider themselves to be on the one hand Taiwanese, and on the other Taiwanese and Chinese (40\% in 1999, 
and $45 \%$ in 2004). Also several surveys show that young Taiwanese recognise themselves in this dual identity more readily: $58 \%$ of the 25-35 age group, as against $37 \%$ of the "over 55" group, and 52\% of the 36-55 age group in 2002. The same survey showed that, conversely, $35 \%$ of the first group considered themselves to be Taiwanese above all, as against $44 \%$ in the second group, and $38 \%$ in the third ${ }^{47}$. Moreover the question was phrased in such a way as to be able to refer either to political identity or to cultural identity, or to both. As we have seen, on a historical level, Taiwanese nationalism is based much more on a state and therefore on a political identity that is separate from the People's Republic, than on a cultural Taiwanicity whose outlines are fluid, shifting and controversial within the island's community itself. It is true that according to several surveys, Taiwanese cultural nationalism is gaining ground: because of the long separation from the mainland and also probably because of the Chen Shui-bian government's voluntarist policy, a majority of Taiwanese believe today that Chinese and Taiwanese culture are different ${ }^{48}$. Nonetheless, polls about the country's future also show that most Taiwanese would not for all that be opposed to a formula which, while maintaining the ROC's sovereignty, would be combined with a form of political union or integration (zhengzhi tonghe) with the People's Republic, as had moreover been proposed by Chen in January 2001 and-as is too often forgottenby Lee Teng-hui in July $1999^{49}$. What these surveys show in reality is that the majority of Taiwanese favour both independence and unification, depending on the circumstances at the time and the conditions on offer ${ }^{50}$. Separatist discourse remains, as we have seen, very much in a minority. In other words, this is why Taiwanese identity and nationalism are not synonymous with support for independence ${ }^{51}$.

In such circumstances how can one credit the idea that the island's three Han communities (98\% of the population) no longer have any ties with Chinese culture, or with Confucian ideology? While Taiwanese culture developed in an autonomous manner, for example in relation to the minnan culture in Fujian, since the beginning of the Hoklo migration to the island, is it possible to call into question the close relationship between these two cultures, and between them and the other facets of Chinese culture? How can one convince native Taiwanese that most of them have aboriginal blood, when historical research has demonstrated that while there was intermingling, the demographic disparities between the Han and the Austronesians contradicted this assertion ${ }^{52}$ ? By giving such importance to blood relationships, are not the Taiwanese nativists producing a mirror image of the Chinese communist approach to the notion of "nationality" (minzu), and are they not perpetuating the most traditional, and racist, interpretation of Han nationalism ${ }^{53}$ ?

There is little doubt that, by over-relying on these ideas, Chen and the Green camp have contributed to weakening not only the internal political consensus but also the vital strategic support provided by the United States to the de facto survival of the ROC. It is a recognised fact that the political class as whole is favourable to the principle of a referendum law or a far-reaching constitutional revision. But the untimely use by chen Shui-bian of the referendum law in March 2004-organising a plebiscite on the military threat from the PLA in order to win more votes-was contested both by half of the electorate and by the Bush administration, which is the American government most favourable to Taiwan since $1968^{54}$. Similarly, Chen had to transform his project for a new Constitution into a plan for "regeneration" of the basic law, in order not to infringe the diplomatic commitments made in May 2000, and reaffirmed four years later, to Washington and Peking ${ }^{55}$. Lastly, the Chen government's hesitation about 
increasing defence efforts, while the Chinese military threat grows steadily, as well as the opposition of much of the Blue camp to the arms sales proposed by the United States, demonstrate how weak is the spirit of defence which should theoretically underlie Taiwanese nationalism. This shows how narrow is the margin of manœuvre of the authorities, and consequently of Taiwanese nationalism.

It is clear that the promulgation in March 2005 by the Chinese National People's Congress of law against secession from the nation (WWWWWW, fan fanlie guojia fa) which reiterates the threat of a resort to force (Article 8) has once again nourished Taiwanese nationalism, producing ipso facto a five point rise in support for independence ${ }^{56}$. However this movement will probably remain in a minority. What this new law has mainly favoured is the strengthening of the Taiwanese consensus against China's persistent refusal to recognise the division of the Chinese nation into two separate states, and the survival of the Republic of China, which was founded in 1912 on part of the national territory. The highly favourable reaction of Taiwanese public opinion to the visits paid to China in the spring of 2005 by the two main opposition leaders (Lien Chan and James Soong) confirm, if it is necessary, the moderation and the limits of Taiwanese nationalism. Above and beyond the differences and institutional stalemates which divide the Green camp from the Blue, the only form of nationalism shared by all Taiwanese is that based on the determination to defend the status quo and the maintenance of an ROC outside the PRC, which is to say a politically Taiwanese nationalism whose relationship with Chinese culture will, however, remain privileged.

All in all, for the reasons we have mentioned, Taiwanese nationalism is not an "ordinary nationalism". It will remain a nationalism which is frustrated by the "sinitude" of its cultural and historical inheritance, by the irredentist claims of Chinese nationalists and by the anti-nationalist "pledges" imposed by the Americans.

Is co-existence between Taiwanese nationalism and Chinese nationalism possible?

In these circumstances, is Taiwanese nationalism capable of rivalling Chinese nationalism? More political than cultural, based more on a state than on ethnicity, more modern and even post-modern than traditional, the former does not possess the absolute, touchy and occasionally racist character of the latter. While the nativist and fundamentalist perversions of Taiwanese nationalism appear in some ways as reversed images of the most conservative and imperial tendencies in Chinese nationalism, they have little likelihood of being embraced by the majority, and of becoming consensual, so complex, globalised, plural-and Chinese-is Taiwanese reality.

Nonetheless, both internally and on the international scene, Taiwan needs its nationalism for it is this new feeling alone which today is capable of maintaining the "sovereignist" and "civic" consensus on which, initially by default and more recently as a plan, is based the existence of the Republic of China in Taiwan. Here one cannot avoid the temptation of establishing a parallel between the current construction of Taiwanese nationalism and the identical process favoured by the political leaders of another predominantly Chinese society, Singapore. However, in contrast with the government in Singapore, Chen Shui-bian's government is engaged in a race against time, the objective of which is to consolidate Taiwanese nationalism before the island's economy and society find themselves completely within the orbit of the People's Republic of China. To some extent, as we have seen, this voluntarism has produced results. But in order to consolidate this nationalism, it will have to cultivate, not so much its ambiguity, as its plural character, its belonging both to the Chinese cultural 
world and to a sovereign Taiwanese nation called the Republic of China. It will have to exclude its most nativist manifestations if it wants to maintain on the island the political consensus necessary for the spirit of defence of a state which is not only called into question, but threatened by a People's Republic of China whose power increases daily. And lastly, Taiwanese nationalism will have to continue to set itself apart from the independence movement if it wishes to guarantee its own survival, which is to say in particular the assurance of American protection, and eventually find grounds for compromise with the most moderate and democratic manifestations of Chinese nationalism. It is only on this basis that the "imagined community" which is the Taiwanese nation will be able to build and prosper. Otherwise, it will continue to fragment and to weaken, and will end up by falling apart.

Translated from the French original by Michael Black

\section{NOTES}

1. I would like to thank the two anonymous commentators on an earlier version of this article, for their stimulating criticisms and suggestions. I remain of course the only one responsible for the point of view and the conclusions set out in this article.

2. Benedict Anderson, Imagined Communities: Reflections on the Origin and Spread of Nationalism, London, New Left, 1983.

3. Ernest Gellner, Nations and Nationalism, Ithaca, Cornell University Press, 1983; Eric Hobsbawm, Nations and Nationalism since 1780: Programme, Myth, Reality, Cambridge, Cambridge University Press, 1990.

4. On Chinese nationalism, cf. our article "The Many Facets of Chinese Nationalism", China Perspectives, No. 59, May-June 2005, pp. 26-40. On the ambiguity and the permanent reconstruction of all nationalisms, and Chinese nationalism in particular, cf. Prasenjit Duara, Culture, Power and the State: Rural North China, 1900-1942, Stanford, Ca., Stanford University Press, 1988.

5. Taiwanese supporters of independence are currently "revisiting" this period in order to make Koxinga a precursor of Taiwanese independence. This became the interpretation of Chen Shui-bian's government's Information Bureau in June 2005, http://www.gio.gov.tw/taiwan-website/5-gp/history. However, as has been shown by Wang Xiaobo, among other historians, in the seventeenth century, as in 1895 and in 1945-1947, the real objective of this "Taiwanese independence movement" was to return Taiwan to a more legitimate Chinese whole. Cf. Taiwan yishi de lishi kaocha (Historical Enquiry into Taiwanese Consciousness), Taipei, Haixia xueshu chubanshe, 2001, pp. 287 and ff.

6. Today Chinese from southern Fujian (Minnan and Hoklo) still make up the majority of the island's population (around 65\%). The Hakka, originally from eastern Guangdong and who also have marked particularities, represent 20\%. The Austronesians, the first inhabitants of the island amount to only $2 \%$ of the population.

7. This objective is deliberately kept quiet by supporters of Taiwanese independence who, like the Vice-President of the Republic of China, Lu Hsiu-lien, for example, believe 
that Shimonoseki set the seal on China's abandonment of Taiwan. The Taiwanese resistance to Japanese occupation is now presented by the Taipei government website as a struggle for independence; for example the "declaration of independence" of May 23rd 1895 appears prominently and Taiwan is described, in the English version, as a "homeland" (http://www.gio.gov.tw/taiwan-website/5-gp/history).

8. Leo T. S. Ching, Becoming Japanese: Colonial Taiwan and Politics of Identity Formation, Berkeley, University of California Press, 2001.

9. The nipponisation of the Taiwanese, while real on the linguistic level, proved to be much more superficial in the realm of culture and ideology, cf. Harry J. Lamley, “Taiwan Under Japanese Rule, 1895-1945”, in Murray A. Rubinstein, Taiwan. A New History, Armonk, N.Y., M. E. Sharpe, 1999, pp. 201-248.

10. Yun-han Chu and Jih-wen Lin, "Political Development in 20th Century Taiwan: State-Building, Regime Transformation and the Construction of National Identity", The China Quarterly, No. 165, March 2001, pp. 102-129.

11. Supporters of Taiwanese independence contest this point, although the demands formulated by island's elites in 1947 as well as all the historiography attest to it, cf. Peng Ming-min, A Taste of Freedom: Memoirs of a Formosan Independence Leader, New York, Holt, Rinehart \& Winston, 1972. Cf. also Denny Roy, Taiwan. A Political History, Ithaca, Cornell University Press, 2003, p. 58.

12. Steven Philips, "Between Assimilation and Independence. Taiwanese Political Aspirations Under Nationalist Chinese Rule, 1945-1948”, in Rubinstein, 1999, op. cit., pp. 301-302 ; Roy, 2003, op. cit., pp. 93-94.

13. Ernest Gellner, 1983, op. cit. ; Eric Hobsbawm, 1990, op. cit.

14. During World War II, the American administration envisaged various status possibilities for Taiwan (including decolonisation, an international mandate, independence, or conditional restitution to China) but President Roosevelt decided to restore the island to China and informed Chiang Kai-shek of this decision well before informing his own administration. Roosevelt's intention was to raise China to the rank of a Great Power and to make it one of the "Four Policemen" responsible for the maintenance of world peace (along with the United States, the United Kingdom and the Soviet Union, but, as we know, without France). Cf. Richard C. Bush, At Cross Purposes. U.S.-Taiwan Relations Since 1942, Armonk, N.Y., M. E. Sharpe, 2003.

15. Peter Chen-main Wang, "A Bastion Created, A Regime Reformed, An Economy Reengineered, 1949-1970", in Rubinstein, op. cit., p. 335.

16. Françoise Mengin, Trajectoires chinoises. Taiwan, Hong Kong et Pékin, Paris, Karthala, 1998, pp. 63-68.

17. A-chin Hsiau, Contemporary Taiwanese Cultural Nationalism, London \& New York, Routledge, 2000, Ch. 4.

18. Alan Wachman, Taiwan: National Identity and Democratization, Armonk, N.Y., M. E. Sharpe, 1997; Christopher Hughes, Taiwan and Chinese Nationalism. National Identity and Status in International Society, London \& New York, Routledge, 1997.

19. On a strictly legal level, in the absence of mutual recognition by the two Chinas and as long as the ROC does not officially redraw its frontiers (which both Peking and Washington oppose), the mainland remains formally under the sovereignty (zhuquan) of the Republic of China, at least in the eyes of Taipei. For Peking, the contrary principle applies. 
20. The principle of self-determination is different from that of independence, and, in theory, is not incompatible with unification with China if this is approved by the majority of Taiwanese.

21. This expression is inspired by the formulation "civic nation-state" proposed by Gunter Schubert on the subject of Taiwan, "Taiwan Political Parties and National identity. The Rise of an Overarching Consensus", Asian Survey, Vol. XLIV, No. 4, JulyAugust 2004, pp. 534-554.

22. The most reliable data are those from the Electoral Studies centre of the Chengchih National University; in December 2004, these were as follows: $45.5 \%$ of those questioned considered themselves to be Taiwanese (the highest percentage ever achieved by this group was in September 2004: 48.3\%), 46.1\% to be Chinese and Taiwanese (as against 49.7\% in March 2004 but 38.4\% in November 2003) and 8.5\% to be Chinese (as against 4.8\% in March 2004 but 9.4\% in May 2003); cf. also Szu-yin Ho and I-chou Liu, "The Taiwanese/Chinese Identity of the Taiwan People in the 1990s", American Asian Review, Vol. XXX, No. 2, Summer 2002, p. 39, p. 42, p. 45.

23. One can have doubts about the second figure, which would show a very rapid fall among the people who consider themselves to be both Taiwanese and Chinese; cf. http://www.taiwanthinktank.org/index1.php.

24. Tu Weiming, "Cultural Identity and the Politics of Recognition in Contemporary Taiwan”, The China Quarterly, No. 148, December 1996, pp. 1115-1140.

25. Laurent Michelon, "Taiwan. Rewriting the Textbooks: An Educational Reform... or a Political One?”, China Perspectives, No. 15, January-February 1998, pp. 52-57; Christopher Hughes \& Robert Stone, "Nation-Building and Curriculum Reform in Hong Kong and Taiwan", The China Quarterly, No. 160, 1999, pp. 977-991; Stéphane Corcuff, "L'introspection han à Formose. L'affaire des manuels scolaires 'Connaître Taiwan', (1994-1997)", Etudes chinoises, vol. XX, No. 1-2, Spring-Autumn 2001, pp. 41-84.

26. Stéphane Corcuff, Une identification plurielle. Les Continentaux et la transition identitaire à Taiwan, 1988-1997, doctoral thesis, Institut d'études politiques de Paris, 2000; “Taiwan's 'Mainlanders', a New Ethnic Category”, China Perspectives, No. 28, March-April 2000, pp. 71-81; “Taiwan's Mainlanders, New Taiwanese?”, in Stéphane Corcuff (ed.), Memories of the Future. National Identity Issues and the Search for a New Taiwan, Armonk, N. Y., M.E. Sharpe, 2002, p. 169.

27. Thus between 1998 and 2005, except during the years $2001-2002,30 \%$ to $40 \%$ of those questioned believed it was more important to develop Taiwan's foreign relations than relations with the mainland; between $20 \%$ and $25 \%$ thought the opposite, while $18 \%$ to $22 \%$ believed that both should be developed at the same time. In December 2004 (as in 2001-2002), because of the tension caused by the announcement of the planned anti-secession law, the first group decreased strongly (22\%) while the third grew considerably (42\%); while the third group remained virtually unchanged (28\%). In August 2005 , the first group amounted to $38.9 \%$, the second to $33.1 \%$ and the third to $17.4 \%$. Over the long term, foreign policy remains a priority in public opinion; $\mathrm{cf}$. the website of the Mainland Affairs Council, www.mac.gov.tw, consulted on November 15th 2005.

28. In August 2005, 72.6\% of Taiwanese were opposed to the formulation proposed by Deng Xiaoping and $11.4 \%$ were in favour, www.mac.gov.tw, consulted on November 15th 2005.

29. In August 2005, $13.8 \%$ of Taiwanese supported reunification, of whom only $2.7 \%$ "as soon as possible" and $20 \%$ supported independence, of whom $5.8 \%$ "as soon as 
possible". Among the 59.5\% of Taiwanese who favoured the status quo, $40.5 \%$ wanted to postpone any decision and 19\% favoured indefinite postponement of any decision; cf. the website of the Mainland Affairs Council, www.mac.gov.tw, consulted on November 15 th 2005.

30. Gilles Guiheux, "Taiwanais en Chine : une émigration à rebours ?", Politique internationale, No. 104, Summer 2004, pp. 383-384.

31. Interview with some Taishang in Shanghai and Kunshan, November 2005.

32. Shih Ming, Taiwanren sibainian (Four Hundred Years of Taiwanese History), San Jose, Ca., Paradise Culture Associates, 1980.

33. With obviously political aims, several specialists are carrying out genetic research on the racial origins of the Taiwanese, in particular the Hoklo and the Hakka and believe that most of them have Austronesian blood. The work of Dr. Chen Shun-sheng, of the Department of Psychiatry of Kaohsiung Hospital is often cited (The China Post, August 10th 2005, http://www.asiafinest.com/forum/lofiversion/index.php/t41351.html).

34. Chang Bi-yu, "From Taiwanisation to De-sinisation. Culture Construction in Taiwan since the 1990s", China Perspectives, No. 56, November-December 2004, pp. 34-44. Daniel C. Lynch, "Taiwan's Self-Conscious Nation-Building Project", Asian Survey, Vol. XLIV, No. 4, July-August 2004, pp. 513-533.

35. In November 2005, the Representative Bureau of Taiwan in France organised a concert in Paris of Nanguan music, presenting this art as being typically Taiwanese, when it actually comes from southern China. The main performer of the troupe, Wang Hsin-hsin, is a native of Quanzhou in Fujian, and only moved to Taiwan about twelve years ago.

36. This initiative prompted a strong reaction from James Soong's People First Party (PFP).

37. http://www.gio.gov.tw/taiwan-website/5-gp/history.

38. Henning Klöter, "Language Policy in the KMT and DPP Eras", China Perspectives, No. 56, November-December 2004, pp. 56-63.

39. Tiaozhan 2008-guojia fazhan zhongdian jihua xilie jianyan (Constructive Discussions on the Challenge of 2008-Principal Aspects of the National development Plan), Taipei, Taiwan zhiku, November 2002, p. 21.

40. Zuqun duoyuan guojia yiti jueyi, September 26th 2004, cf. http://www.dpp.org.tw; English translation, "Resolution on Ethnic Diversity and National Unity", Taiwan Review, January 2005, p. 11. Peculiar to Taiwan and developed by nationalist sociologists, the concept of zuqun is different from that of ethnic group ( $\mathrm{minzu}$ ) but is deliberately close to it, often creating ambiguity in English and in the other Western languages.

41. Dafydd Fell, "Inner-Party Competition in Taiwan since the 1990s", China Perspectives, No. 56, November-December 2004, pp. 3-13.

42. He let it be known in August 2005 that he had an aboriginal grandmother from the Pingpu tribe, stating that such was also the case of eight out of ten Taiwanese which thus confirmed the results of the research carried out by some supporters of independence. The China Post, August 10th 2005.

43. Frank Muyard, "Taiwan, the birth of a nation?", China Perspectives, No. 53, May-June 2004, pp 33-48.

44. In December 2001, the results were as follows: KMT 68 seats; PFP 46; DPP 87 and TSU 13. 
45. For a close and balanced reading of these elections, cf. Frank Muyard, "KMT: A Trompe-l'œil Victory. The December 2004 Taiwanese Legislative Elections”, China Perspectives, No. 58, March-April 2005, pp. 43-54.

46. Christopher Hughes, Taiwan and Chinese Nationalism. National Identity and Status in International Society, London \& New York, Routledge, 1997, pp. 95 and ff.

47. Yun-han Chu, “Taiwan's National Identity Politics and the Prospects of Cross-Strait Relations”, Asian Survey, Vol. XLIV, No. 4, July-August 2004, p. 502.

48. T. Y. Wang \& I-Chou Liu, "Contending Identities in Taiwan. Implications for CrossStrait Relations”, Asian Survey, Vol. XLIV, No. 4, July-August 2004, pp. 568-589.

49. In his speech on inter-state relations with China, cf. www.fas.org/news/taiwan/ 1999/0709.htm.

50. Emerson M. S. Niou, "Understanding Taiwan Independence and Its Policy Implications”, Asian Survey, Vol. XLIV, No. 4, July-August 2004, pp. 555-567.

51. Wu Nai-teh, "Rentong chayi de jiaxiang he zuqun chongtu" (The misleading appearances of differences in identity and inter-community conflict in Taiwan), Zhongguo shibao (China Times), May 12th 2004, p. A6.

52. Melissa J. Brown, Is Taiwan Chinese? The Impact of Culture, Power, and Migration on Changing Identities, Berkeley, Ca., University of California Press, 2004.

53. Frank Dikötter, The Discourse of Race in Modern China, London, Hurst and Co., 1992.

54. Jean-Pierre Cabestan, "Chen Shui-bian et le triangle Taipei-Pékin-Washington", Critique internationale, $\mathrm{n}^{\circ}$ 24, juillet 2004, pp. 51-65.

55. One of these commitments is not to change the name, flag or national anthem of the country, which is to say the Republic of China.

56. Asia Times Online, March $19^{\text {th }} 2005$. 